\title{
Genetic and environmental predictors of serum 25-hydroxyvitamin D concentrations among middle-aged and elderly Chinese in Singapore
}

\author{
Kim Robien ${ }^{1,2 *}$, Lesley M. Butler ${ }^{3}$, Renwei Wang ${ }^{4}$, Kenneth B. Beckman ${ }^{5}$, Dinesha Walek ${ }^{5}$, \\ Woon-Puay $\mathrm{Koh}^{6}$ and Jian-Min Yuan ${ }^{4,7}$ \\ ${ }^{1}$ Division of Epidemiology and Community Health, School of Public Health, University of Minnesota, 1300 South 2nd Street, \\ Suite 300, Minneapolis, MN 55455, USA \\ ${ }^{2}$ Masonic Cancer Center, University of Minnesota, MMC 807 Mayo, 8807A, 420 Delaware Street, SE, Minneapolis, \\ MN 55455, USA \\ ${ }^{3}$ Environmental and Radiological Health Sciences, Colorado State University, $148 B$ EH Building, 1681 Campus Delivery, \\ Fort Collins, CO 80523-1681, USA \\ ${ }^{4}$ University of Pittsburgh Cancer Institute, UPMC Cancer Pavillion, Suite 4C-464, 5150 Center Avenue, Pittsburgh, \\ PA 15232, USA \\ ${ }^{5}$ Biomedical Genomics Center, University of Minnesota, MMC 501 Mayo, 8501, 420 Delaware Street, SE, Minneapolis, \\ MN 55455, USA \\ ${ }^{6}$ Saw Swee Hock School of Public Health, National University of Singapore, MD3, 16 Medical Drive, Singapore 117597, \\ Singapore \\ ${ }^{7}$ Department of Epidemiology, Graduate School of Public Health, University of Pittsburgh, Pittsburgh, PA, USA
}

(Submitted 18 June 2011 - Final revision received 12 March 2012 - Accepted 14 March 2012 - First published online 15 May 2012)

\section{Abstract}

Vitamin D is known for maintaining Ca homeostasis and bone structure, and may also decrease susceptibility to chronic and infectious diseases. However, data on vitamin D status and its predictors among Southeast Asian populations are limited. We evaluated the distribution and determinants (genetic and environmental) of serum 25-hydroxyvitamin D (25(OH)D) concentrations among 504 middleaged and elderly participants (aged 45-74 years) in the Singapore Chinese Health Study. Data on dietary and other lifestyle factors were collected by trained interviewers. Serum $25(\mathrm{OH}) \mathrm{D}$ concentrations and genetic polymorphisms in vitamin D metabolism pathway enzymes (cytochrome P450 (CYP) 2R1, 3A4, 27B1, 24A1; vitamin D binding protein (also known as group-specific component, GC); and vitamin D receptor) were measured using stored biospecimens. Mean 25(OH)D concentration was $68.8 \mathrm{nmol} / 1$. Serum $25(\mathrm{OH}) \mathrm{D}$ concentrations were positively associated with dietary vitamin D intake, and inversely associated with hours spent sitting at work. BMI was not associated with 25(OH)D concentrations. CYP2R1 rs10741657, rs12794714, rs1993116; CYP3A4 rs2242480; and GC rs4588, rs7041, rs16847015, rs2298849 were statistically significantly associated with $25(\mathrm{OH}) \mathrm{D}$ concentrations. Individuals with the $G c 2-2$ haplotype (rs4588AA/rs7041TT) had statistically significantly lower $25(\mathrm{OH}) \mathrm{D}$ concentrations compared to all other $G c$ haplotypes ( $P$-trend $<0 \cdot 001)$. The majority of participants $(86 \%)$ had $25(\mathrm{OH}) \mathrm{D}$ concentrations $\geq 50 \mathrm{nmol} / \mathrm{l}$, which is consistent with the 2011 Institute of Medicine (US) recommendation for bone health, and $32 \%$ had concentrations of $\geq 75 \mathrm{nmol} / 1$ that are thought to be required for broader health effects. Dietary vitamin D intake, hours spent indoors at work and genetic variation in CYP2R1, CYP3A4 and GC are significant predictors of 25(OH)D concentrations among Singapore Chinese.

Key words: 25-Hydroxyvitamin D: CYP2R1: CYP3A4: Group-specific component

Vitamin D (as the 1,25-dihydroxyvitamin D metabolite) is a steroid hormone that is well known for its role in maintaining Ca homeostasis and normal bone structure. Recent evidence suggests that in addition to Ca homeostasis, the vitamin may also play a role in a variety of other physiological processes such as modulation of inflammatory pathways ${ }^{(1)}$ and susceptibility to diabetes ${ }^{(2)}$, cancer $^{(3)}$, and infectious ${ }^{(4)}$ and cardiovascular ${ }^{(5)}$ diseases. Thus, the nutrient could play a significant role in public health.

In the USA, the Institute of Medicine recently proposed $\geq 50 \mathrm{nmol} / 1(20 \mathrm{ng} / \mathrm{ml})$ as the definition of vitamin D adequacy based solely on requirements to optimise bone health, due to

Abbreviations: 25(OH)D, 25-hydroxyvitamin D; CYP, cytochrome P450; GC, group-specific component; NIST, National Institute of Standards and Technology; rs, reference SNP; SCHS, Singapore Chinese Health Study; VDR, vitamin D receptor.

*Corresponding author: Dr K. Robien, fax +1 612624 0315, email robie004@umn.edu 
a lack of data to support recommendations for the prevention of other disease endpoints ${ }^{(6)}$. However, many leading vitamin $\mathrm{D}$ researchers continue to recommend serum 25-hydroxyvitamin D (25(OH)D) concentrations of $\geq 75 \mathrm{nmol} / \mathrm{l}(30 \mathrm{ng} / \mathrm{ml})$ to achieve the broader health benefits ${ }^{(7-10)}$.

Season, UVB exposure, skin pigmentation, age, race, sex, obesity and dietary/supplemental vitamin $\mathrm{D}$ intake have all been previously reported to influence serum $25(\mathrm{OH}) \mathrm{D}$ concentrations $^{(11)}$. However, the effect of genetic variation in the vitamin D synthesis and metabolism pathway on circulating concentrations is less well understood. Vitamin D enters the circulation through the activation of vitamin $\mathrm{D}$ precursors by UV radiation on the skin to produce cholecalciferol, or via absorption of dietary or supplemental ergo- or cholecalciferol from the intestinal tract. It is then converted to $25(\mathrm{OH}) \mathrm{D}$ via 25-hydroxylases (cytochrome P450 (CYP) 2R1, 27A1 and $3 \mathrm{~A} 4)$ in the liver ${ }^{(11)}$. Further hydroxylation of $25(\mathrm{OH}) \mathrm{D}$ via $1 \alpha$-hydroxylase (CYP27B1) in the kidney or at the local tissue level produces 1,25-dihydroxycholecalciferol ${ }^{(11)}$. Catabolism of vitamin D metabolites occurs via 24-hydroxylase (CYP24A1) $^{(11)}$. Vitamin D binding protein (also known as group-specific component, GC) is the transport protein for vitamin D metabolites in circulation ${ }^{(12)}$. Genetic variation in any of these steps has the potential to alter serum $25(\mathrm{OH}) \mathrm{D}$ concentrations.

Previous studies have identified SNP in the vitamin D receptor $(V D R)^{(13-20)}, C Y P 2 R 1^{(21-26)}, C Y P 27 B 1^{(22,23,27)}$ and $G C^{(19,24-26,28-35)}$ genes to be associated with alterations in serum $25(\mathrm{OH}) \mathrm{D}$ concentrations. These studies were primarily conducted among Caucasian populations living at higher latitudes with significant seasonal variation in UV exposure, and only a small number of studies have considered environmental vitamin D exposures or personal characteristics as potential effect modifiers.

Data on the distribution and determinants of serum 25(OH)D concentrations in Southeast Asian populations are limited. In this cross-sectional observational study, we evaluated the distribution of serum $25(\mathrm{OH}) \mathrm{D}$ concentrations, and identified genetic, dietary and lifestyle predictors of serum $25(\mathrm{OH}) \mathrm{D}$ concentrations among middle-aged and older Chinese men and women in Singapore. As Singapore is $1^{\circ}$ north of the equator, this study population provides a unique opportunity to evaluate the factors associated with vitamin D status in the absence of seasonal variation in UV exposure, which confounds studies conducted at higher latitudes.

\section{Methods}

The Singapore Chinese Health Study (SCHS) is a populationbased prospective cohort study of 63257 Singapore Chinese men and women (aged 45-74 years) that was assembled between 1993 and 1998 to elucidate the role of diet and genetic factors in the causation of human cancer. Participants in the study were recruited from among permanent residents or citizens of singapore who resided in government-built housing estates, and were one of the two major dialect groups of Singapore Chinese, Hokkien or Cantonese.
At recruitment, each study subject was interviewed in person by a trained interviewer using a structured questionnaire that included questions on lifestyle, health behaviours and sociodemographic factors, as well as a 165-item FFQ. The FFQ was specifically designed to assess the dietary habits of Chinese in Singapore, and was subsequently validated using multiple $24 \mathrm{~h}$ dietary recalls ${ }^{(36)}$. However, because vitamin D is technically challenging to measure in food ${ }^{(37)}$, data on vitamin D contained in the nutrient databases used to analyse FFQ for epidemiological studies (including the US Department of Agriculture database used for the SCHS vitamin D analysis) are known to be incomplete ${ }^{(38)}$. Thus, our estimates probably underestimate the participants' actual dietary vitamin D intake. The only form of supplemental vitamin $\mathrm{D}$ intake to be assessed was cod liver oil; data on frequency of use over the year before the interview were collected and considered for use in this analysis. Participants were not asked specifically about time spent indoors $v$. outdoors; however, participants were asked about the average number of hours spent 'sitting at work' each day, and hours spent doing 'vigorous work such as moving heavy furniture, loading or unloading trucks, shovelling or equivalent manual labour'. Responses to these questions were included in our analyses as surrogates for time spent indoors ('sitting at work') and outdoors ('vigorous work').

Beginning in April 1994, a random 3\% sample of cohort participants was also asked to provide blood or buccal cells, and spot urine samples as a pilot study to determine the feasibility of a larger biospecimen collection effort within the cohort. Details of the biospecimen collection, processing and storage procedures have been described ${ }^{(39)}$. The first 504 SCHS participants who provided biospecimens were included in this substudy. This study was conducted according to the guidelines laid down in the Declaration of Helsinki and all procedures involving human subjects were approved by the Institutional Review Boards of the National University of Singapore and the University of Minnesota. Written informed consent was obtained from all participants.

\section{Serum 25-hydroxyvitamin D assay}

Quantitative determination of serum 25(OH)D concentrations was performed using a direct, competitive chemiluminescence immunoassay on the DiaSorin LIAISON platform ${ }^{(40)}$ by Heartland Assays, a laboratory participating in the Vitamin D External Quality Assessment Scheme ${ }^{(41)}$. This assay measures total $25(\mathrm{OH}) \mathrm{D}$ (both the ergocalciferol $\left(\mathrm{D}_{2}\right)$ and cholecalciferol $\left(\mathrm{D}_{3}\right)$ derived $25(\mathrm{OH}) \mathrm{D}$ metabolites; the assay does not discriminate between the two forms). Two types of blinded controls were randomly interspersed among the study samples for quality control purposes: (1) pooled blood samples ( $n$ 10), and (2) vitamin D standard (standard reference material 972, Vitamin D in Human Serum) from the US National Institute of Standards and Technology $(\mathrm{NIST})^{(42)}$ ( $n$ 16). Mean inter- and intra-batch $\mathrm{CV}$ for the $25(\mathrm{OH}) \mathrm{D}$ concentrations in the pooled blood samples was $6 \cdot 1$ and $5 \cdot 4 \%$, respectively, which is consistent with those of previously published reports ${ }^{(43-47)}$. For the NIST standard level $1\left(58.0 \mathrm{nmol} / 125(\mathrm{OH}) \mathrm{D}_{3}\right.$ in unaltered 
human serum), the mean inter-batch CV was $6 \cdot 2 \%$. Similarly, for the NIST standard level $2\left(4 \cdot 18 \mathrm{nmol} / 125(\mathrm{OH}) \mathrm{D}_{2}\right.$ and $30 \cdot 0 \mathrm{nmol} /$ $125(\mathrm{OH}) \mathrm{D}_{3}$ in diluted human serum), the mean inter-batch $\mathrm{CV}$ was $5 \cdot 2 \%$. The CV for the NIST standards were well below those of previously published reports ${ }^{(48)}$. A number of studies have demonstrated that $25(\mathrm{OH}) \mathrm{D}$ is extremely stable with longterm storage (as long as 40 years) and under a variety of storage conditions ${ }^{(49-52)}$. Thus, our samples, which were stored for an average of 13 (SD 1.2) years, should have experienced little, if any, 25(OH)D degradation, and any degradation would have been consistent across all samples.

\section{SNP selection}

Using a candidate pathway approach, we included common genetic variants (minor allele frequency $\geq 20 \%$ ) of genes involved in 25(OH)D synthesis (CYP2R1, CYP3A4, CYP27B1), transport $(G C)$, gene transcription $(V D R)$ and catabolism (CYP24A1). Data from the International HapMap Project (Tagger Pairwise method, HapMap Data Release 27 Phase II + III, February 2009, on NCBI B36 assembly, dbSNP b126 for the Han Chinese in Beijing, China (CHB) population) were used to identify haplotype tagging SNP for the Han Chinese. No HapMap tag SNP were identified for CYP27A1 in the $\mathrm{CHB}$ population. Also, any SNP that had been documented in the literature as having functional and/or phenotypic relevance were included.

A total of fifty-five SNP and eight proxies met the inclusion criteria (by rs (reference SNP) number, proxies in parentheses): VDR: 731236 also known as TaqI, 1540339, 1544410 also known as BsmI, 2107301 (12717991), 2189480, 2228570 also known as FokI (and previously reported as rs10735810), 2238136, 2239180, 2239182, 2239184, 2239186, 2254210, 2283342, 2525044, 2853564, 2853559, 3782905, 3847987, 4760658, 7305032, 739837, 757343, 7965281, 7975232 also known as ApaI, 10783215, 10875695 (7136534), 11168268 (11168266), 11168275, 11168287, 11574143, 12721364. CYP2R1: 1993116, 12794714 (10500804), 10741657. CYP3A4: 2242480, 2246709, 3735451. CYP27B1: 4646536. CYP24A1: 912505, 2181874, 2209314, 2296241 (2585428), 2762941, 3787555, 4809958 (6068816), 6022999. GC: 4588 (2298850), 7041, 10488854, 12512631, 16847015, 222016, 2298849 (3733359), 705117, 705120

\section{DNA extraction and genotype determinations}

DNA extraction and genotype determinations were performed by the University of Minnesota's BioMedical Genomics Center. DNA was extracted from buffy coats using a Qiagen Kit (Qiagen, Inc.). Genotype determinations were performed on the commercially available high-throughput genotyping SequenomMassARRAY platform (Sequenom, Inc.). Uniquely located negative controls were routinely included in each plate. These wells were used as controls for genotyping assays, and their unique locations serve as a fingerprint to identify the plate and its orientation. For quality control purposes, only SNP with $>95 \%$ call rates were included in the analyses. All SNP were found to be in Hardy-Weinberg equilibrium, except $G C$ rs4588. Genotyping for rs4588 was repeated using a TaqMan assay (Invitrogen). The data from the TaqMan assay were found to be in Hardy-Weinberg equilibrium, and were used for all analyses.

\section{Data analysis}

The distribution of serum $25(\mathrm{OH}) \mathrm{D}$ in the study population was markedly skewed towards low values. Thus, the statistical analyses were performed on logarithmically transformed values, and geometric means are presented. ANOVA methods were used to compare mean serum concentrations of $25(\mathrm{OH}) \mathrm{D}$ by potential lifestyle, sociodemographic, dietary and genetic predictors of $25(\mathrm{OH}) \mathrm{D}$ concentration. Dialect group, education level, menopausal status (women), BMI, height, weight, body surface area, physical activity, smoking status, hours spent sitting at work, season of blood draw, use of cod liver oil supplements and dietary intake of vitamin D, Ca, fish, dairy products and alcohol were considered as potential predictors. Age, sex and time interval between last meal and blood draw were included as covariates in all analyses. Dietary vitamin D and hours spent sitting at work were also included as covariates in ANOVA for the assessment of genetic predictors. To test for linear trend, the potential predictor was included as an ordinal variable in general linear models. Each potential predictor was examined individually by assessing its effect on the overall model fit ( $R^{2}, F$-test). The final multivariate model for non-genetic predictors of serum 25(OH)D concentrations included age, sex, dietary vitamin D intake, hours spent sitting at work, and time interval between last meal and blood draw.

Associations between single SNP and serum 25(OH)D concentrations were evaluated individually in the multivariateadjusted models. Trends in serum 25(OH)D concentrations across each SNP genotype were tested for statistical significance by including the SNP as a three-level variable (homozygous wildtype, heterozygous and homozygous variant).

All $P$ values quoted are two-tailed, and significance was defined as $P<0 \cdot 05$. For the SNP analyses, statistical significance was defined as $P \leq 0 \cdot 01$ to minimise the likelihood of reporting false-positive findings due to multiple comparisons. Calculations were performed using the SAS statistical software system (SAS Institute).

\section{Results}

The study population was $56 \%$ women, and the mean age of study participants was 55.7 years (Table 1 ). Most women were postmenopausal at baseline. Compared to men, women were less educated, less likely to be a smoker, spent less time sitting at work or in vigorous work, and consumed less dietary vitamin D. Mean serum 25(OH)D concentration was $68.6 \mathrm{nmol} / 1$ overall, and lower in women (mean: $64.2 \mathrm{nmol} / \mathrm{l}$ ) than in men $(74.3 \mathrm{nmol} / 1, \quad P<0.001)$, and a greater percentage of women $(18 \%)$ had $25(\mathrm{OH}) \mathrm{D}$ concentrations $<50 \mathrm{nmol} / 1 \mathrm{com}-$ pared to men $(9 \%)$.

Serum $25(\mathrm{OH}) \mathrm{D}$ concentrations were statistically significantly associated with dietary vitamin D, Ca and dairy product 
Table 1. Characteristics of subjects within the Singapore Chinese Health Study, overall and by sex (Mean values, standard deviations, ranges, number of subjects and percentages)

\begin{tabular}{|c|c|c|c|c|c|c|c|}
\hline & \multicolumn{2}{|c|}{ Overall } & \multicolumn{2}{|c|}{ Men } & \multicolumn{2}{|c|}{ Women } & \multirow[b]{2}{*}{$P^{\star}$} \\
\hline & $n$ & $\%$ & $n$ & $\%$ & $n$ & $\%$ & \\
\hline Subjects & 504 & & 220 & $43 \cdot 7$ & 284 & $56 \cdot 3$ & - \\
\hline Age (years) & \multirow{2}{*}{\multicolumn{2}{|c|}{$55 \cdot 7$}} & \multirow{2}{*}{\multicolumn{2}{|c|}{$56 \cdot 3$}} & & & 0.12 \\
\hline Mean & & & & & \multicolumn{2}{|c|}{$55 \cdot 2$} & \\
\hline SD & \multicolumn{2}{|c|}{$7 \cdot 8$} & \multicolumn{2}{|c|}{$7 \cdot 6$} & \multicolumn{2}{|c|}{8.0} & \\
\hline Dialect group & & & & & & & 0.03 \\
\hline Cantonese & 217 & $43 \cdot 1$ & 83 & $37 \cdot 7$ & 134 & $47 \cdot 2$ & \\
\hline Hokkien & 287 & $56 \cdot 9$ & 137 & $62 \cdot 3$ & 150 & $52 \cdot 8$ & \\
\hline Post-menopause (yes) & \multicolumn{2}{|c|}{-} & \multicolumn{2}{|c|}{-} & 197 & $69 \cdot 4$ & - \\
\hline Highest level of education & & & & & & & $<0.001$ \\
\hline No education & 138 & $27 \cdot 4$ & 27 & $12 \cdot 3$ & 111 & $39 \cdot 1$ & \\
\hline Primary & 206 & $40 \cdot 9$ & 104 & $47 \cdot 3$ & 102 & $35 \cdot 9$ & \\
\hline$\geq$ Secondary & 160 & $31 \cdot 8$ & 89 & $40 \cdot 5$ & 71 & $25 \cdot 0$ & \\
\hline BMI $\left(\mathrm{kg} / \mathrm{m}^{2}\right)$ & & & & & & & 0.7 \\
\hline Mean & \multicolumn{2}{|c|}{$22 \cdot 8$} & \multicolumn{2}{|c|}{$22 \cdot 8$} & \multicolumn{2}{|c|}{$22 \cdot 9$} & \\
\hline SD & \multirow{2}{*}{\multicolumn{2}{|c|}{$\begin{array}{c}3 \cdot 0 \\
13 \cdot 5-37 \cdot 1\end{array}$}} & \multirow{2}{*}{\multicolumn{2}{|c|}{$\begin{array}{c}3.0 \\
13.5-32.1\end{array}$}} & \multicolumn{2}{|c|}{3.0} & \\
\hline Range & & & & & \multicolumn{2}{|c|}{$15 \cdot 8-37 \cdot 1$} & \\
\hline Smoking status & \multicolumn{2}{|c|}{$13 \cdot 5-37 \cdot 1$} & & & & & $<0.001$ \\
\hline Never & 368 & $73 \cdot 0$ & 98 & 44.6 & 270 & $95 \cdot 1$ & \\
\hline Ever & 136 & $27 \cdot 0$ & 122 & $55 \cdot 5$ & 14 & 4.9 & \\
\hline Hours spent sitting at work, $\geq 3 \mathrm{~h} / \mathrm{d}$ & 106 & $21 \cdot 0$ & 68 & $30 \cdot 9$ & 38 & $13 \cdot 4$ & $<0.001$ \\
\hline Vigorous work, $\geq 0.5 \mathrm{~h}$ per week & 32 & $6 \cdot 4$ & 20 & $9 \cdot 1$ & 12 & $4 \cdot 2$ & 0.03 \\
\hline Cod liver oil supplements (weekly) (yes) & 14 & $2 \cdot 8$ & 8 & 3.6 & 6 & $2 \cdot 1$ & 0.3 \\
\hline Dietary vitamin D ( $\mu \mathrm{g} / \mathrm{d})$ & \multirow{2}{*}{\multicolumn{2}{|c|}{$2 \cdot 6$}} & & & & & 0.02 \\
\hline Mean & & & \multicolumn{2}{|c|}{$2 \cdot 8$} & \multicolumn{2}{|c|}{2.4} & \\
\hline SD & \multicolumn{2}{|c|}{1.7} & \multicolumn{2}{|c|}{1.8} & \multicolumn{2}{|c|}{$1 \cdot 7$} & \\
\hline Serum 25(OH)D (nmol/l) & & & & & & & $<0.001$ \\
\hline Mean & \multicolumn{2}{|c|}{68.6} & \multicolumn{2}{|c|}{74.3} & & & \\
\hline SD & & & & & & & \\
\hline Range & $27 \cdot 0$ & $53 \cdot 5$ & $37 \cdot 2$ & 53.5 & $27 \cdot 0$ & $25 \cdot 9$ & - \\
\hline Categories & & & & & & & $<0.001$ \\
\hline$<50.0 \mathrm{nmol} / \mathrm{l}$ & 72 & $14 \cdot 3$ & 20 & $9 \cdot 1$ & 52 & $18 \cdot 3$ & \\
\hline $50.0-74.9 \mathrm{nmol} / \mathrm{l}$ & 271 & $53 \cdot 8$ & 103 & $46 \cdot 8$ & 168 & $59 \cdot 2$ & \\
\hline$\geq 75.0 \mathrm{nmol} / \mathrm{l}$ & 161 & 31.9 & 97 & $44 \cdot 1$ & 64 & $22 \cdot 5$ & \\
\hline
\end{tabular}

25(OH)D, 25-hydroxyvitamin D.

${ }^{*} \chi^{2}$ or $t$ test $P$-values for differences by sex for categorical and continuous variables, respectively.

intake among women, but not men (Table 2). Serum 25(OH)D levels decreased with increasing number of hours spent sitting at work for both men and women, although the linear relationship was not statistically significant for women. There were no associations with 25(OH)D concentrations for cod liver oil supplement use, fish intake or time between last meal and blood draw, regardless of sex (data not shown). Women engaging in vigorous work for at least half an hour per week showed significantly higher serum $25(\mathrm{OH}) \mathrm{D}$ level compared to their counterparts with no vigorous work, whereas there was no difference in serum $25(\mathrm{OH}) \mathrm{D}$ level between men with and without vigorous work. Age, BMI, alcohol intake and working status were not associated with serum $25(\mathrm{OH}) \mathrm{D}$ concentration in this population. When age, sex, dietary vitamin $\mathrm{D}$ intake, hours spent sitting at work, and time interval between last meal and blood draw were considered simultaneously in the final multivariate model, $10 \cdot 2 \%$ of the variation in serum $25(\mathrm{OH}) \mathrm{D}$ concentrations was explained $(P<0 \cdot 01)$.

Of the fifty-five SNP assessed, eight SNP in CYP2R1, CYP3A4 and GC were associated with $25(\mathrm{OH}) \mathrm{D}$ concentrations (Table 3). For five of the SNP, the major allele was associated with lower $25(\mathrm{OH}) \mathrm{D}$ concentrations (e.g. CYP2R1 rs10741657 and rs1993116; and GC rs7041, rs2298849 and rs1687015), while for the remaining three SNP, the major allele was associated with higher $25(\mathrm{OH}) \mathrm{D}$ concentrations (e.g. CYP2R1 rs12794714; CYP3A4 rs2242480; and $G C$ rs4588). The strongest association was with the GC SNP rs4588, where the decrease in copies of the major allele (e.g. from 2 to 0 ) was associated with a $11.5 \mathrm{nmol} / \mathrm{l}$ decrease in serum $25(\mathrm{OH}) \mathrm{D}$ concentration $(P<0 \cdot 001)$. Including genotype information for individual SNP into the multivariable model explained an additional $0.8-3.7 \%$ of the variation in serum $25(\mathrm{OH}) \mathrm{D}$ concentrations in this cohort (Table 3 ).

In addition to the single-SNP associations with serum $25(\mathrm{OH}) \mathrm{D}$ concentrations, we also evaluated the combined effect of two well-described GC SNP, rs4588 and rs7041. These SNP have been previously shown to jointly determine three well-described protein transcripts: Gc1s, Gc1f and $\mathrm{Gc}^{(12)}$. As shown in Table 4, the mean $25(\mathrm{OH}) \mathrm{D}$ concentration was the highest for individuals with two copies of the Gc1s allele (Gc1s-1s: rs4588CC, rs7041GG), the lowest for individuals with two copies of the Gc2 allele (Gc2-2: rs4588AA, rs7041TT), and intermediate for those with any other $G C$ haplotype ( $P$-trend <0.001). When stratified by median dietary vitamin $\mathrm{D}$ intake, the trends with $25(\mathrm{OH}) \mathrm{D}$ 
Table 2. Geometric means of 25 -hydroxyvitamin $\mathrm{D}(25(\mathrm{OH}) \mathrm{D})$ by potential predictors overall and by sex

(Mean values and standard deviations)

\begin{tabular}{|c|c|c|c|c|c|c|c|c|c|}
\hline \multirow[b]{3}{*}{ Potential predictors } & \multicolumn{3}{|c|}{ Overall ( $n$ 504) } & \multicolumn{3}{|c|}{ Men (n 220) } & \multicolumn{3}{|c|}{ Women ( $n$ 284) } \\
\hline & \multirow[b]{2}{*}{$n$} & \multicolumn{2}{|c|}{ 25(OH)D (nmol/l) } & \multirow[b]{2}{*}{$n$} & \multicolumn{2}{|c|}{$25(\mathrm{OH}) \mathrm{D}(\mathrm{nmol} / \mathrm{l})$} & \multirow[b]{2}{*}{$n$} & \multicolumn{2}{|c|}{ 25(OH)D (nmol/l) } \\
\hline & & Mean* & SD & & Mean* & SD & & Mean* & SD \\
\hline \multicolumn{10}{|l|}{ Median age (years) } \\
\hline$<55.0$ & 252 & $67 \cdot 1$ & 0.02 & 98 & $71 \cdot 7$ & 0.04 & 154 & $64 \cdot 4$ & 0.03 \\
\hline$\geq 55.0$ & 252 & 65.5 & 0.02 & 122 & $72 \cdot 0$ & 0.03 & 130 & $58 \cdot 7$ & 0.03 \\
\hline$P$ & & 0.5 & & & 0.9 & & & 0.1 & \\
\hline \multicolumn{10}{|c|}{ Work status at blood draw } \\
\hline Not working & 276 & 66.5 & 0.02 & 128 & $72 \cdot 4$ & 0.02 & 148 & $62 \cdot 3$ & 0.02 \\
\hline Working & 228 & $66 \cdot 1$ & 0.02 & 92 & $71 \cdot 2$ & 0.03 & 136 & $62 \cdot 3$ & 0.02 \\
\hline$P$ & & 0.8 & & & 0.6 & & & 0.9 & \\
\hline \multicolumn{10}{|l|}{ BMI $\left(\mathrm{kg} / \mathrm{m}^{2}\right) \dagger$} \\
\hline$\leq 23 \cdot 0$ & 244 & $65 \cdot 9$ & 0.02 & 109 & $72 \cdot 6$ & 0.02 & 135 & $61 \cdot 0$ & 0.02 \\
\hline$>23.0$ & 260 & $66 \cdot 7$ & 0.02 & 111 & $71 \cdot 2$ & 0.02 & 149 & 63.5 & 0.02 \\
\hline$P$ & & 0.6 & & & 0.6 & & & 0.2 & \\
\hline \multicolumn{10}{|l|}{ Vitamin D intake } \\
\hline Tertile $1 \ddagger$ & 183 & $64 \cdot 6$ & 0.02 & 85 & $72 \cdot 1$ & 0.03 & 98 & 58.9 & 0.02 \\
\hline Tertile 2 & 149 & $66 \cdot 3$ & 0.02 & 70 & 73.9 & 0.03 & 79 & $62 \cdot 0$ & 0.03 \\
\hline Tertile 3 & 172 & $68 \cdot 2$ & 0.02 & 65 & $69 \cdot 9$ & 0.03 & 107 & $66 \cdot 6$ & 0.03 \\
\hline$P$ & & 0.04 & & & 0.5 & & & $<0.001$ & \\
\hline \multicolumn{10}{|l|}{ Ca intake } \\
\hline Tertile $1 \S$ & 160 & $64 \cdot 8$ & 0.02 & 84 & 71.4 & 0.03 & 76 & 59.8 & 0.03 \\
\hline Tertile 2 & 154 & $66 \cdot 4$ & 0.02 & 70 & 73.0 & 0.03 & 84 & 61.0 & 0.03 \\
\hline Tertile 3 & 190 & 67.5 & 0.02 & 66 & 71.4 & 0.03 & 124 & $65 \cdot 9$ & 0.03 \\
\hline$P$ & & 0.18 & & & 0.9 & & & 0.03 & \\
\hline \multicolumn{10}{|l|}{ Dairy product intake } \\
\hline Tertile 19 & 177 & $63 \cdot 2$ & 0.02 & 74 & $68 \cdot 2$ & 0.03 & 103 & $59 \cdot 3$ & 0.02 \\
\hline Tertile 2 & 147 & 68.4 & 0.02 & 74 & 77.5 & 0.03 & 73 & $61 \cdot 7$ & 0.03 \\
\hline Tertile 3 & 180 & $67 \cdot 7$ & 0.02 & 72 & 71.0 & 0.03 & 108 & $66 \cdot 1$ & 0.03 \\
\hline$P$ & & 0.005 & & & 0.4 & & & 0.002 & \\
\hline Alcohol intake, drinks $/ \mathrm{w}$ & & & & & & & & & \\
\hline 0 & 418 & $66 \cdot 0$ & 0.01 & 153 & $70 \cdot 8$ & 0.02 & 265 & $62 \cdot 2$ & 0.02 \\
\hline$<7$ & 63 & 66.5 & 0.03 & 48 & 74.2 & 0.4 & 15 & $66 \cdot 0 \|$ & 0.08 \\
\hline$\geq 7$ & 23 & $70 \cdot 9$ & 0.3 & 19 & $75 \cdot 3$ & 0.06 & 4 & & \\
\hline$P$ & & 0.3 & & & 0.2 & & & 0.5 & \\
\hline Vigorous work (h/week) & & & & & & & & & \\
\hline 0 & 472 & $66 \cdot 0$ & 0.01 & 200 & 71.7 & 0.02 & 272 & 61.9 & 0.02 \\
\hline$\geq 0.5$ & 32 & 71.0 & 0.05 & 20 & $73 \cdot 7$ & 0.06 & 12 & $72 \cdot 4$ & 0.07 \\
\hline$P$ & & 0.1 & & & 0.7 & & & 0.03 & \\
\hline Hours spent sitting at $w$ & & & & & & & & & \\
\hline None & 291 & $68 \cdot 1$ & 0.02 & 115 & $75 \cdot 3$ & 0.02 & 176 & $62 \cdot 9$ & 0.02 \\
\hline$<1$ & 62 & $66 \cdot 4$ & 0.03 & 18 & $76 \cdot 0$ & 0.06 & 44 & $61 \cdot 0$ & 0.04 \\
\hline $1-2$ & 45 & $68 \cdot 0$ & 0.04 & 19 & 69.5 & 0.06 & 26 & $67 \cdot 1$ & 0.05 \\
\hline $3-6$ & 68 & $63 \cdot 0$ & 0.03 & 42 & $67 \cdot 7$ & 0.04 & 26 & $60 \cdot 6$ & 0.05 \\
\hline$\geq 7$ & 38 & $57 \cdot 2$ & 0.04 & 26 & $63 \cdot 6$ & 0.05 & 12 & 52.9 & 0.07 \\
\hline$P$ & & $<0.001$ & & & 0.001 & & & 0.2 & \\
\hline Smoking status & & & & & & & & & \\
\hline Never & 368 & $66 \cdot 0$ & 0.01 & 98 & $70 \cdot 7$ & 0.03 & 270 & $62 \cdot 4$ & 0.02 \\
\hline Former & 57 & $67 \cdot 2$ & 0.04 & 55 & $71 \cdot 7$ & 0.04 & 2 & $58 \cdot 2$ & $0 \cdot 2$ \\
\hline Current & 79 & $67 \cdot 2$ & 0.03 & 67 & 73.7 & 0.03 & 12 & 59.8 & 0.07 \\
\hline$P$ & & $0 . \overline{6}$ & & & 0.3 & & & 0.5 & \\
\hline Season of blood draw & & & & & & & & & \\
\hline February-April & 124 & 64.5 & 0.02 & 51 & $68 \cdot 3$ & 0.04 & 73 & $61 \cdot 6$ & 0.03 \\
\hline May-July & 142 & $67 \cdot 6$ & 0.02 & 63 & $76 \cdot 7$ & 0.03 & 79 & $61 \cdot 2$ & 0.03 \\
\hline August-October & 131 & $66 \cdot 8$ & 0.02 & 58 & $70 \cdot 9$ & 0.03 & 73 & $63 \cdot 8$ & 0.03 \\
\hline November-January & 107 & $66 \cdot 1$ & 0.02 & 48 & $70 \cdot 9$ & 0.04 & 59 & $62 \cdot 7$ & 0.03 \\
\hline$P$ & & 0.6 & & & 0.9 & & & 0.5 & \\
\hline
\end{tabular}

${ }^{\star}$ Mean values were adjusted for age (years), sex (among overall) and time interval from last meal to blood draw.

† Asian-specific BMI cut-points were used ${ }^{(54)}$

† Median values of dietary vitamin $D$ intake for tertiles $(\mu \mathrm{g} / 4.184 \mathrm{~kJ})$ were: $0.8,1.4$ and 2.5 , respectively, for all subjects; $0.9,1.4$ and 2.4 , respectively, among men; and 0.8 , 1.6 and $2 \cdot 8$, respectively, among women.

$\S$ Median values of dietary Ca intake for tertiles (mg/4.184 kJ) were: 177, 214 and 362, respectively, for all subjects; 168,217 and 309 , respectively, among men; and 185,260 and 395, respectively, among women.

ๆ Median values of dairy product intake (g/4.184 kJ) were: $1.3,14.4$ and 118 , respectively, for all subjects; $1 \cdot 1,10 \cdot 8$ and $77 \cdot 0$, respectively, among men; and $1.5,17 \cdot 3$ and 134 , respectively, among women.

\| Among women, only geometric means for none or any alcohol and beer intake is presented, as only nine women reported drinking any alcohol. 
by haplotype are similar to the overall pattern currently presented in Table 4 for both high and low dietary vitamin D intake (data not shown). However, when stratified by hours spent sitting at work, the trend of decreasing $25(\mathrm{OH}) \mathrm{D}$ concentration from $G c 1 s-1 s$ to $G c 2-2$ haplotype was only evident among those who reported no hours spent sitting at work ( $n$ 268, $P$-trend $<0 \cdot 001$, Table 5). The trend was less evident and was not statistically significant among those who reported any sitting hours at work (data not shown), although the interaction between $G c$ haplotype and hours spent sitting at work was not statistically significant $(P$-interaction $=0 \cdot 24)$.

\section{Discussion}

On average, participants in this study had serum 25(OH)D concentrations that would be considered sufficient for optimal bone health according to the Institute of Medicine recommendations $^{(6)}$, but somewhat below the recommendations from leading vitamin D researchers of $75 \mathrm{nmol} / 1$ to address a broader range of health concerns ${ }^{(7)}$. However, the serum $25(\mathrm{OH}) \mathrm{D}$ concentrations for participants in this study were higher, on average, than has been reported for comparably aged men $(58.0 \mathrm{nmol} / \mathrm{l})$ and women $(54.8 \mathrm{nmol} / \mathrm{l})$ in the $\mathrm{USA}^{(53)}$, which might be expected of individuals living near the equator.
BMI was not associated with serum 25(OH)D concentrations in this population, mostly probably due to the fact that the mean BMI for the study participants was within the normal range for Asian populations $\left(<23 \mathrm{~kg} / \mathrm{m}^{2}\right)^{(54)}$, and the range was narrow. Mean dietary vitamin $\mathrm{D}$ intake for these middle- and older-aged Singaporean men (2.8 (SD 1.8) $\mu \mathrm{g} / \mathrm{d}$ ) and women $(2 \cdot 4(\mathrm{SD} 1.7) \mu \mathrm{g} / \mathrm{d})$ was lower than comparably aged men $(5.1(\mathrm{SD} 0.3) \mu \mathrm{g} / \mathrm{d})$ and women $(3.9(\mathrm{SD} 0.4) \mu \mathrm{g} / \mathrm{d})$ in the USA according to the 2005-6 National Health and Nutrition Examination Survey data ${ }^{(55)}$, and somewhat lower than adult men $(3 \cdot 1(\mathrm{SD} 0 \cdot 1) \mu \mathrm{g} / \mathrm{d})$ and women $(2 \cdot 7(\mathrm{SD} 0 \cdot 1) \mu \mathrm{g} / \mathrm{d})$ in the UK according to the 2008-9 National Diet and Nutrition Survey data ${ }^{(56)}$.

Sun exposure is known to be a major determinant of vitamin D status. Singapore receives $12 \mathrm{~h}$ sunlight/d throughout the year, with a midday solar zenith angle that ranges from a minima of $0-3^{\circ}$ (March, September) to a peak of $22-25^{\circ}$ (June, December $)^{(57)}$. Despite a small amount of variation in solar zenith angle, we did not observe significant seasonal variation in serum $25(\mathrm{OH}) \mathrm{D}$ concentrations in this cohort. The UV index ranges from 10 (December) to 13 (March/April), indicating very high ambient UV radiation levels ${ }^{(58)}$. Given the average daily high temperatures of $31^{\circ} \mathrm{C}\left(88^{\circ} \mathrm{F}\right)^{(59)}$, many Singaporeans avoid the heat of the midday sun. In our study, as the reported

Table 3. Geometric means of serum 25-hydroxyvitamin $\mathrm{D}(25(\mathrm{OH}) \mathrm{D})$ by genotype

(Geometric mean values and $95 \%$ confidence intervals)

\begin{tabular}{|c|c|c|c|c|c|c|c|}
\hline & \multirow[b]{2}{*}{ Genotype } & \multirow[b]{2}{*}{$n$} & \multicolumn{2}{|c|}{$25(\mathrm{OH}) \mathrm{D}(\mathrm{nmol} / \mathrm{l})$} & \multirow[b]{2}{*}{$P$ for trend } & \multirow{2}{*}{$\begin{array}{c}\text { Variance explained by the } \\
\text { model (\%)† }\end{array}$} & \multirow{2}{*}{$\begin{array}{l}\text { Variance explainec } \\
\text { by genotype (\%)‡ }\end{array}$} \\
\hline & & & Geometric mean* & $95 \% \mathrm{Cl}$ & & & \\
\hline \multicolumn{8}{|l|}{ CYP2R1 } \\
\hline \multirow{3}{*}{ rs10741657 } & GG & 253 & 64.9 & $62 \cdot 9,67 \cdot 0$ & 0.02 & $11 \cdot 1$ & $1 \cdot 0$ \\
\hline & $\mathrm{GA}$ & 192 & $67 \cdot 6$ & $65 \cdot 3,70 \cdot 0$ & & & \\
\hline & AA & 50 & $70 \cdot 0$ & $65 \cdot 3,75 \cdot 3$ & & & \\
\hline \multirow[t]{3}{*}{ rs12794714 } & GG & 197 & $69 \cdot 2$ & $66.8,71 \cdot 7$ & $<0.001$ & $13 \cdot 3$ & $3 \cdot 1$ \\
\hline & GA & 242 & $66 \cdot 0$ & $64 \cdot 0,68 \cdot 2$ & & & \\
\hline & AA & 58 & $58 \cdot 6$ & $54.9,62.5$ & & & \\
\hline \multirow[t]{3}{*}{ rs1993116 } & $\mathrm{CC}$ & 248 & $64 \cdot 6$ & $62 \cdot 6,66 \cdot 7$ & 0.04 & $11 \cdot 4$ & 0.8 \\
\hline & $\mathrm{CT}$ & 201 & $67 \cdot 8$ & $65.5,70 \cdot 2$ & & & \\
\hline & TT & 42 & $68 \cdot 5$ & $63.5,73.9$ & & & \\
\hline \multicolumn{8}{|l|}{ CYP3A4 } \\
\hline \multirow[t]{3}{*}{ rs2242480 } & $\mathrm{CC}$ & 258 & 68.5 & $66 \cdot 4,70 \cdot 6$ & 0.008 & 11.5 & $1 \cdot 3$ \\
\hline & $\mathrm{CT}$ & 199 & 63.9 & $61 \cdot 7,66 \cdot 2$ & & & \\
\hline & $\mathrm{TT}$ & 40 & 64.5 & $59 \cdot 6,69 \cdot 7$ & & & \\
\hline \multicolumn{8}{|l|}{$G C$} \\
\hline \multirow[t]{3}{*}{ rs4588 } & $\mathrm{CC}$ & 267 & $68 \cdot 7$ & $66 \cdot 7,70 \cdot 8$ & $<0.001$ & $13 \cdot 3$ & $3 \cdot 7$ \\
\hline & CA & 173 & $64 \cdot 3$ & $61 \cdot 9,66 \cdot 8$ & & & \\
\hline & AA & 39 & $57 \cdot 2$ & $52 \cdot 8,61 \cdot 9$ & & & \\
\hline \multirow[t]{3}{*}{ rs7041 } & $\mathrm{TT}$ & 226 & $64 \cdot 0$ & $61 \cdot 9,66 \cdot 1$ & 0.003 & $12 \cdot 0$ & 1.6 \\
\hline & $\mathrm{TG}$ & 212 & $67 \cdot 7$ & $65 \cdot 4,70 \cdot 0$ & & & \\
\hline & GG & 53 & $70 \cdot 6$ & $65.9,75.6$ & & & \\
\hline \multirow[t]{3}{*}{ rs2298849 } & $\mathrm{TT}$ & 176 & 63.9 & $61 \cdot 6,66 \cdot 3$ & 0.001 & $12 \cdot 7$ & $2 \cdot 1$ \\
\hline & TC & 237 & $66 \cdot 1$ & $64 \cdot 0,68 \cdot 3$ & & & \\
\hline & $\mathrm{CC}$ & 77 & $72 \cdot 2$ & $68 \cdot 2,76 \cdot 4$ & & & \\
\hline \multirow[t]{3}{*}{ rs16847015 } & $\mathrm{CC}$ & 275 & $64 \cdot 1$ & $62 \cdot 2,66 \cdot 0$ & 0.002 & $12 \cdot 8$ & 1.9 \\
\hline & $\mathrm{CA}$ & 175 & 68.5 & $66 \cdot 0,71 \cdot 1$ & & & \\
\hline & AA & 39 & $70 \cdot 8$ & $65 \cdot 5,76 \cdot 6$ & & & \\
\hline
\end{tabular}

CYP2R1, cytochrome P450 2R1; rs, refSNP or reference SNP; CYP3A4, cytochrome P450 3A4, GC, group-specific component (vitamin D binding protein).

*25(OH)D concentrations are multivariate-adjusted for: age, sex, dietary vitamin $D$, hours spent sitting at work, and time interval between last meal and blood draw.

† Variance explained is the model $R^{2} \times 100$. The partial $R^{2}$ for each of the covariates in the individual multivariate models was: age $(<0.001)$, sex $(0.070-0.076)$, dietary vitamin D (0.005-0.008), hours spent sitting at work (0.020-0.026), and time interval between last meal and blood draw $(<0.001)$.

$\ddagger$ The variance explained by genotype is the partial $R^{2} \times 100$ for the individual genotype in a linear regression model with variables for age, sex, dietary vitamin $\mathrm{D}$, hours spent sitting at work, and time interval between last meal and blood draw. 
number of hours spent sitting at work increased, serum $25(\mathrm{OH}) \mathrm{D}$ concentrations decreased $(P$-trend $<0.001)$.

Three other reports have described serum $25(\mathrm{OH}) \mathrm{D}$ concentrations among healthy adults living within $10^{\circ}$ of the equator. Rahman et al. ${ }^{(60)}$ evaluated 276 post-menopausal women living near Kuala Lumpur, Malaysia $\left(2^{\circ} \mathrm{N}\right)$. They found that ethnic Chinese women had significantly higher mean 25(OH)D concentrations compared to Malay women (68.8 (sD 15.7) v. $44.4(10.6) \mathrm{nmol} / \mathrm{l}, P<0.05$ ). Dietary vitamin $\mathrm{D}$ intake did not differ between the two ethnic groups. The Chinese women had a significantly lower mean BMI, and reported more regular physical activity than the Malay women. The Malay also tend to have more skin pigmentation than the Chinese, and many Malay women follow Muslim dress codes that further limit UV exposure. Serum 25(OH)D concentrations were significantly correlated with BMI, fat mass, parathyroid hormone concentrations and physical activity scores. Green et al. ${ }^{(61)}$ evaluated 378 younger women living in Kuala Lumpur (mean age: $25 \cdot 2$ years) and 126 women living in Jakarta, Indonesia $\left(6^{\circ} \mathrm{S}\right.$, mean age: $30 \cdot 0$ years). Among the women in Malaysia, they also found higher serum 25(OH)D concentrations among the ethnic Chinese (mean: $58.0 \mathrm{nmol} / 1,95 \% \mathrm{CI} 55.0,61.0$ ) compared to the Malay (mean: $43 \cdot 0 \mathrm{nmol} / 1,95 \% \mathrm{CI} 40 \cdot 0,46 \cdot 0$ ) or Indian (mean: $45 \cdot 0 \mathrm{nmol} / 1,95 \% \mathrm{CI} 43 \cdot 0,48 \cdot 0)$ women $(P<0 \cdot 01)$. The Indonesian women had serum $25(\mathrm{OH}) \mathrm{D}$ concentrations that were comparable to the Malay and Indian women (mean: $46.0 \mathrm{nmol} / 1$, $95 \%$ CI $43 \cdot 0,48 \cdot 0)$. Moy \& Bulgiba ${ }^{(62)}$ recently reported on the vitamin D status of 380 Malay study participants (158 men, 222 women) in a voluntary health screening programme in Kuala Lumpur. The women had significantly lower serum 25(OH)D concentrations (mean: $36 \cdot 2 \mathrm{nmol} / 1,95 \% \mathrm{CI} 34 \cdot 5,38 \cdot 0$ ) compared to the men (mean: $56 \cdot 2 \mathrm{nmol} / 1,95 \%$ CI $53 \cdot 2,59 \cdot 2, P<0 \cdot 001$ ), which could be partially explained by differences in religious dress codes. Age, sex, BMI and abdominal obesity were found to be statistically significantly associated with vitamin D insufficiency in this study cohort. The women in our study had serum $25(\mathrm{OH}) \mathrm{D}$ concentrations that were similar to the ethnic Chinese participants in both the Rahman et al. ${ }^{(60)}$ and Green et al. ${ }^{(61)}$ studies.

Genetic variants in CYP2R1, CYP3A4 and GC were significantly associated with serum $25(\mathrm{OH}) \mathrm{D}$ concentrations in our study. The CYP2R1 rs10741657, rs12794714, and rs1993116 and $G C$ rs 4588 and rs7041 findings are consistent with several recent reports ${ }^{(19,21,26,28-32,34,35)}$, including two large genomewide association studies ${ }^{(24,25)}$. Several CYP enzymes have been shown to have 25-hydroxylase activity, and CYP2R1 has emerged as the predominant 25-hydroxylase, with the highest binding affinity and specificity for vitamin $D^{(63)}$ CYP2R1 rs10741657 lies in the promoter region, rs12794714 is a synonymous SNP in exon 1, and rs1993116 is in intron 1. To our knowledge, no previous studies have evaluated the association between genetic variation in CYP3A4 and serum 25(OH)D concentrations in human subjects. CYP3A4 rs2242480 is in intron 10 near the exon/intron boundary. Although the functional relevance of this SNP is unclear, a recent pharmacokinetic study suggests that individuals with 
the homozygous variant rs2242480TT genotype have significantly lower CYP3A4 activity ${ }^{(64)}$.

The GC SNP, rs4588 and rs7041, are both in exon 11. Consistent with the findings of several previous studies ${ }^{(19,28,65-68)}$, we also observed that individuals with two copies of the Gc2 allele (Gc2-2) have significantly lower 25(OH)D concentrations compared to other $G C$ genotypes. In vitro data have shown that the Gc2 protein has a significantly lower affinity constant for $25(\mathrm{OH}) \mathrm{D}_{3}$ compared to the Gc1s or Gc1f proteins $^{(12)}$. GC rs16847015 and rs2298849 both lie in intron 1, and their functional relevance is unclear.

While several previous reports identified genetic variants in the $V D R^{(13-20)}$ and $C Y P 27 B 1^{(22,23,27)}$ genes as being associated with serum 25(OH)D concentrations, we did not observe any statistically significant associations for those genes in our study population. The studies reporting significant findings for $V D R$ and $C Y P 27 B 1$ variants tended to be among smaller study populations, conducted at higher latitudes, and many failed to adjust for factors known to alter serum 25(OH)D concentrations such as season of blood draw, BMI and dietary/ supplemental vitamin D intake.

The present study has several strengths including being the largest study of vitamin D status among Southeast Asians to date, lack of seasonal UV variation, and consideration of dietary vitamin $\mathrm{D}$ exposures, lifestyle and sociodemographic factors as well as genetic variation as potential factors contributing to serum 25(OH)D concentrations. We also took a comprehensive approach to assessing the effect of genetic variation in the entire vitamin D metabolism pathway, as opposed to the evaluation of single candidate genes or SNP. Limitations of the present study include incomplete assessment of time spent outdoors during daylight hours and degree of skin pigmentation, factors which may contribute to variation in serum 25(OH)D concentrations. Due to technical challenges in accurately measuring the vitamin D content of foods ${ }^{(37,38)}$, our assessment of the participants' dietary vitamin D intake is probably underestimated. This underestimation of dietary vitamin $\mathrm{D}$ intake should occur to all study subjects non-differentially, which would result in underestimating the association between dietary vitamin $\mathrm{D}$ intake and serum 25(OH)D concentrations. Supplemental vitamin D intake, other than cod liver oil, was not specifically assessed. However, only $8 \%$ of our study cohort reported taking any vitamins or minerals at least once a week.

Our findings confirm the growing body of literature documenting an association between $G C$ and $C Y P 2 R 1$ genetic variation and serum $25(\mathrm{OH}) \mathrm{D}$ concentrations. Future studies of both predictors of $25(\mathrm{OH}) \mathrm{D}$ concentrations and disease outcomes thought to be associated with vitamin D status should include an assessment of $G C$ and CYP2R1 genotype. Further research is needed to confirm our findings related to CYP3A4 rs2242480.

\section{Acknowledgements}

The authors' contributions to the present study were as follows: K. R., L. M. B. and J.-M. Y. were responsible for the study concept and design and obtainment of funding; K. R. was responsible 
for study supervision; K. R., K. B. B., D. W., W.-P. K. and J.-M. Y. for the acquisition of data; L. M. B., R. W., K. R. and J.-M. Y. for the data analysis and interpretation; and K. R. and L. M. B. for drafting of the manuscript. All authors contributed to critical revision of the manuscript. None of the authors reported a conflict of interest. The authors thank Siew-Hong Low of the National University of Singapore for supervising the fieldwork of the SCHS, and Kazuko Arakawa for the development and maintenance of the cohort study database. Further, the authors acknowledge the founding, long-standing Principal Investigator of the SCHS - Mimi C. Yu. This study was funded by the University of Minnesota Masonic Cancer Center and the National Cancer Institute (R01 CA144034).

\section{References}

1. Cohen-Lahav M, Douvdevani A, Chaimovitz C, et al. (2007) The anti-inflammatory activity of 1,25-dihydroxyvitamin $\mathrm{D}_{3}$ in macrophages. J Steroid Biochem Mol Biol 103, 558-562.

2. Boucher BJ (2011) Vitamin D insufficiency and diabetes risks. Curr Drug Targets 12, 61-87.

3. World Health Organization, International Agency for Research on Cancer (IARC) (2008) Vitamin D and Cancer. Working Group Report 5. Lyon: WHO.

4. Baeke F, Takiishi T, Korf H, et al. (2010) Vitamin D: modulator of the immune system. Curr Opin Pharmacol 10, 482-496.

5. Reddy Vanga S, Good M, Howard PA, et al. (2010) Role of vitamin $\mathrm{D}$ in cardiovascular health. Am J Cardiol 106, $798-805$.

6. Institute of Medicine (2011) Dietary Reference Intakes for Vitamin D and Calcium [AC Ross, CL Taylor, AL Yaktine and HB Del Valle, editors]. Washington, DC: Institute of Medicine.

7. Vieth R, Bischoff-Ferrari H, Boucher BJ, et al. (2007) The urgent need to recommend an intake of vitamin D that is effective. Am J Clin Nutr 85, 649-650.

8. Heaney RP \& Holick MF (2011) Why the IOM recommendations for vitamin D are deficient. J Bone Miner Res 26, $455-457$.

9. Norman AW (2011) Vitamin D nutrition is at a crossroads. Public Health Nutr 14, 744-745.

10. Schwalfenberg GK \& Whiting SJ (2011) A Canadian response to the 2010 Institute of Medicine vitamin D and calcium guidelines. Public Health Nutr 14, 746-748.

11. Holick MF (2007) Vitamin D deficiency. N Engl J Med 357, 266-281.

12. Speeckaert M, Huang G, Delanghe JR, et al. (2006) Biological and clinical aspects of the vitamin $\mathrm{D}$ binding protein (Gc-globulin) and its polymorphism. Clin Chim Acta 372, 33-42.

13. Ma J, Stampfer MJ, Gann PH, et al. (1998) Vitamin D receptor polymorphisms, circulating vitamin D metabolites, and risk of prostate cancer in United States physicians. Cancer Epidemiol Biomarkers Prev 7, 385-390.

14. Ogunkolade BW, Boucher BJ, Prahl JM, et al. (2002) Vitamin $\mathrm{D}$ receptor (VDR) mRNA and VDR protein levels in relation to vitamin D status, insulin secretory capacity, and VDR genotype in Bangladeshi Asians. Diabetes 51, 2294-2300.

15. d'Alesio A, Garabedian M, Sabatier JP, et al. (2005) Two single-nucleotide polymorphisms in the human vitamin D receptor promoter change protein-DNA complex formation and are associated with height and vitamin $\mathrm{D}$ status in adolescent girls. Hum Mol Genet 14, 3539-3548.
16. Zajickova K, Hill M, Vankova M, et al. (2006) Low-density lipoprotein receptor-related protein 5 and vitamin $\mathrm{D}$ receptor gene polymorphisms in relation to vitamin D levels in menopause. Clin Chem Lab Med 44, 1066-1069.

17. Vupputuri MR, Goswami R, Gupta N, et al. (2006) Prevalence and functional significance of 25-hydroxyvitamin D deficiency and vitamin $\mathrm{D}$ receptor gene polymorphisms in Asian Indians. Am J Clin Nutr 83, 1411-1419.

18. Baroncelli GI, Bereket A, El Kholy M, et al. (2008) Rickets in the Middle East: role of environment and genetic predisposition. J Clin Endocrinol Metab 93, 1743-1750.

19. Engelman CD, Fingerlin TE, Langefeld CD, et al. (2008) Genetic and environmental determinants of 25-hydroxyvitamin D and 1,25-dihydroxyvitamin D levels in Hispanic and African Americans. J Clin Endocrinol Metab 93, 3381-3388.

20. Smolders J, Damoiseaux J, Menheere P, et al. (2009) Fok-I vitamin D receptor gene polymorphism (rs10735810) and vitamin D metabolism in multiple sclerosis. J Neuroimmunol 207, 117-121.

21. Ramos-Lopez E, Bruck P, Jansen T, et al. (2007) CYP2R1 (vitamin D 25-hydroxylase) gene is associated with susceptibility to type 1 diabetes and vitamin D levels in Germans. Diabetes Metab Res Rev 23, 631-636.

22. Orton SM, Morris AP, Herrera BM, et al. (2008) Evidence for genetic regulation of vitamin $\mathrm{D}$ status in twins with multiple sclerosis. Am J Clin Nutr 88, 441-447.

23. Ramos-Lopez E, Kahles H, Weber S, et al. (2008) Gestational diabetes mellitus and vitamin D deficiency: genetic contribution of CYP27B1 and CYP2R1 polymorphisms. Diabetes Obes Metab 10, 683-685.

24. Wang TJ, Zhang F, Richards JB, et al. (2010) Common genetic determinants of vitamin $\mathrm{D}$ insufficiency: a genome-wide association study. Lancet 376, 180-188.

25. Ahn J, Yu K, Stolzenberg-Solomon R, et al. (2010) Genomewide association study of circulating vitamin D levels. Hum Mol Genet 19, 2739-2745.

26. Bu FX, Armas L, Lappe J, et al. (2010) Comprehensive association analysis of nine candidate genes with serum 25-hydroxy vitamin D levels among healthy Caucasian subjects. Hum Genet 128, 549-556.

27. Hypponen E, Berry DJ, Wjst M, et al. (2009) Serum 25-hydroxyvitamin $\mathrm{D}$ and $\mathrm{IgE}$ - a significant but nonlinear relationship. Allergy 64, 613-620.

28. Kurylowicz A, Ramos-Lopez E, Bednarczuk T, et al. (2006) Vitamin D-binding protein (DBP) gene polymorphism is associated with Graves' disease and the vitamin D status in a Polish population study. Exp Clin Endocrinol Diabetes 114, 329-335.

29. Lauridsen AL, Vestergaard P, Hermann AP, et al. (2005) Plasma concentrations of 25-hydroxy-vitamin D and 1,25dihydroxy-vitamin $\mathrm{D}$ are related to the phenotype of $\mathrm{Gc}$ (vitamin D-binding protein): a cross-sectional study on 595 early postmenopausal women. Calcif Tissue Int 77, 15-22.

30. Abbas S, Linseisen J, Slanger T, et al. (2008) The Gc2 allele of the vitamin $\mathrm{D}$ binding protein is associated with a decreased postmenopausal breast cancer risk, independent of the vitamin D status. Cancer Epidemiol Biomarkers Prev 17, $1339-1343$.

31. Sinotte M, Diorio C, Berube S, et al. (2009) Genetic polymorphisms of the vitamin $\mathrm{D}$ binding protein and plasma concentrations of 25-hydroxyvitamin D in premenopausal women. Am J Clin Nutr 89, 634-640.

32. Fu L, Yun F, Oczak M, et al. (2009) Common genetic variants of the vitamin $\mathrm{D}$ binding protein (DBP) predict differences in response of serum 25-hydroxyvitamin D [25(OH)D] to vitamin D supplementation. Clin Biochem 42, 1174-1177. 
33. Ahn J, Albanes D, Berndt SI, et al. (2009) Vitamin D-related genes, serum vitamin $\mathrm{D}$ concentrations and prostate cancer risk. Carcinogenesis 30, 769-776.

34. Fang Y, van Meurs JB, Arp P, et al. (2009) Vitamin D binding protein genotype and osteoporosis. Calcif Tissue Int $\mathbf{8 5}$, $85-93$.

35. Janssens W, Bouillon R, Claes B, et al. (2010) Vitamin D deficiency is highly prevalent in COPD and correlates with variants in the vitamin D-binding gene. Thorax 65, 215-220.

36. Hankin JH, Stram DO, Arakawa K, et al. (2001) Singapore Chinese Health Study: development, validation, and calibration of the quantitative food frequency questionnaire. Nutr Cancer 39, 187-195.

37. Byrdwell WC, Devries J, Exler J, et al. (2008) Analyzing vitamin D in foods and supplements: methodologic challenges. Am J Clin Nutr 88, 554S-557S

38. Holden JM, Lemar LE \& Exler J (2008) Vitamin D in foods: development of the US Department of Agriculture database. Am J Clin Nutr 87, 1092S-1096S.

39. Koh WP, Yuan JM, Sun CL, et al. (2003) Angiotensin I-converting enzyme (ACE) gene polymorphism and breast cancer risk among Chinese women in Singapore. Cancer Res 63, 573-578.

40. Ersfeld DL, Rao DS, Body JJ, et al. (2004) Analytical and clinical validation of the $25 \mathrm{OH}$ vitamin D assay for the LIAISON automated analyzer. Clin Biochem 37, 867-874.

41. Carter GD, Carter CR, Gunter E, et al. (2004) Measurement of Vitamin D metabolites: an international perspective on methodology and clinical interpretation. J Steroid Biochem Mol Biol 89-90, 467-471.

42. Tai SS, Bedner M \& Phinney KW (2010) Development of a candidate reference measurement procedure for the determination of 25-hydroxyvitamin $\mathrm{D}_{3}$ and 25-hydroxyvitamin $\mathrm{D}_{2}$ in human serum using isotope-dilution liquid chromatography-tandem mass spectrometry. Anal Chem 82, 1942-1948.

43. Giovannucci E, Liu Y, Rimm EB, et al. (2006) Prospective study of predictors of vitamin D status and cancer incidence and mortality in men. $J$ Natl Cancer Inst 98, 451-459.

44. Bertone-Johnson ER, Chen WY, Holick MF, et al. (2005) Plasma 25-hydroxyvitamin D and 1,25-dihydroxyvitamin D and risk of breast cancer. Cancer Epidemiol Biomarkers Prev 14, 1991-1997.

45. Freedman DM, Chang SC, Falk RT, et al. (2008) Serum levels of vitamin D metabolites and breast cancer risk in the prostate, lung, colorectal, and ovarian cancer screening trial. Cancer Epidemiol Biomarkers Prev 17, 889-894.

46. Abbas S, Linseisen J, Slanger T, et al. (2008) Serum 25-hydroxyvitamin D and risk of post-menopausal breast cancerresults of a large case-control study. Carcinogenesis 29 , 93-99.

47. Cauley JA, Lacroix AZ, Wu L, et al. (2008) Serum 25-hydroxyvitamin D concentrations and risk for hip fractures. Ann Intern Med 149, 242-250.

48. Gallicchio L, Helzlsouer KJ, Chow WH, et al. (2010) Circulating 25-hydroxyvitamin $\mathrm{D}$ and the risk of rarer cancers: design and methods of the Cohort Consortium Vitamin D Pooling Project of Rarer Cancers. Am J Epidemiol 172, $10-20$.

49. Zerwekh JE (2004) The measurement of vitamin D: analytical aspects. Ann Clin Biochem 41, 272-281.

50. Hollis BW (2008) Measuring 25-hydroxyvitamin D in a clinical environment: challenges and needs. Am J Clin Nutr $\mathbf{8 8}, 507$ S -510 S
51. Antoniucci DM, Black DM \& Sellmeyer DE (2005) Serum 25hydroxyvitamin $\mathrm{D}$ is unaffected by multiple freeze-thaw cycles. Clin Chem 51, 258-261.

52. Bodnar LM, Catov JM, Wisner KL, et al. (2009) Racial and seasonal differences in 25-hydroxyvitamin D detected in maternal sera frozen for over 40 years. Br J Nutr 101, $278-284$.

53. Looker AC, Johnson CL, Lacher DA, et al. (2011) Vitamin D Status: United States, 2001-2006. NCHS Data Brief, No. 59. Hyattsville, MD: National Center for Health Statistics.

54. Choo V (2002) WHO reassesses appropriate body-mass index for Asian populations. Lancet 360, 235.

55. Bailey RL, Dodd KW, Goldman JA, et al. (2010) Estimation of total usual calcium and vitamin D intakes in the United States. J Nutr 140, 817-822.

56. Bates B, Lennox A \& Swan G (editors) (2010) National Diet Nutrition Survey (2008/2009). London: Food Standards Agency, Department of Health.

57. Cornwall C, Horiuchi A \& Lehman C (2011) NOAA Solar Position Calculator. National Oceanic and Atmospheric Administration Earth System Research Lab. http://www.srrb.noaa. gov/highlights/sunrise/azel.html (accessed 23 April 2011).

58. World Health Organization (2011) Ultraviolet Radiation and the INTERSUN Programme: UV Index. http://www.who. int/uv/intersunprogramme/activities/uv_index/en/index3. html (accessed 23 April 2011).

59. Department of Statistics, Ministry of Trade and Industry, Republic of Singapore (2011) Monthly Digest of Statistics Singapore, March 2011. Republic of Singapore: Ministry of Trade and Industry.

60. Rahman SA, Chee WS, Yassin Z, et al. (2004) Vitamin D status among postmenopausal Malaysian women. Asia Pac J Clin Nutr 13, 255-260.

61. Green TJ, Skeaff CM, Rockell JE, et al. (2008) Vitamin D status and its association with parathyroid hormone concentrations in women of child-bearing age living in Jakarta and Kuala Lumpur. Eur J Clin Nutr 62, 373-378.

62. Moy FM \& Bulgiba A (2011) High prevalence of vitamin D insufficiency and its association with obesity and metabolic syndrome among Malay adults in Kuala Lumpur, Malaysia. BMC Public Health 11, 735.

63. Schuster I (2011) Cytochromes P450 are essential players in the vitamin D signaling system. Biochim Biophys Acta 1814, 186-199.

64. Zhang W, Chang YZ, Kan QC, et al. (2010) CYP3A4*1G genetic polymorphism influences CYP3A activity and response to fentanyl in Chinese gynecologic patients. Eur J Clin Pharmacol 66, 61-66.

65. Daiger SP, Miller M \& Chakraborty R (1984) Heritability of quantitative variation at the group-specific component (Gc) locus. Am J Hum Genet 36, 663-676.

66. Lauridsen AL, Vestergaard P \& Nexo E (2001) Mean serum concentration of vitamin D-binding protein (Gc globulin) is related to the Gc phenotype in women. Clin Chem $\mathbf{4 7}$, 753-756.

67. Brown IR, Carter ND \& Sood A (1979) Vitamin D binding globulin phenotypes in liver disease. Clin Chim Acta 95, $75-82$.

68. Constans J, Arlet P, Viau M, et al. (1983) Unusual sialilation of the serum DBP associated with the Gc 1 allele in alcoholic cirrhosis of the liver. Clin Chim Acta 130, 219-230. 